\title{
Content-Based English Education in China: Students' Experiences and Perspectives
}

\author{
Gulbahar H. Beckett and Fang Li \\ becketgh@ucmail.uc.edu
}

\begin{abstract}
This study explores undergraduate students' experiences and perceptions of the content-based EFL instruction at a northwestern Chinese university. It is one of the first empirical studies of content-based EFL in China. Through a three-part open-ended questionnaire administered with 34 undergraduate students majoring in finance, the study reveals overwhelming support for this approach to EFL. Participants believed that learning English and content knowledge simultaneously was helpful and that the spread of English in China can benefit the nation and its people. The findings also indicate that some participants were critical of the approach, stating that it is "shallow content teaching" and suggesting that subject matter content be taught in Chinese. The participants praised their original English texts and expressed their preference for student-centered learning.
\end{abstract}

\section{Background}

English as a Foreign Language (EFL) education in China focused on language form, teaching it separately, until the turn of the $21^{\text {st }}$ century, when the focus shifted to language function in response to dissatisfaction with repetitive, inefficient, and exam-oriented EFL pedagogy. The perceived need for an English-proficient workforce for the 2008 Summer Olympics and the World Trade Organization (WTO) entry was a catalyst for that shift. Scholars proposed content-based EFL (e.g., W. Y. Zhang, 2001; Z. B. Zhang, 2003) as an approach to teach the form and function of English language simultaneously, as they believed that that would better equip learners with both the oracy and the literacy necessary for the contemporary labour market (Cai, 2010; Feng, 2009). A content-based approach promotes language development through the use of language as the medium of subject-matter content (e.g., social studies, science) in the target language with a focus on language forms, rules, and content learning rather than an exclusive focus on mastery of the target language forms (e.g., Mohan \& Beckett, 2003). Researchers believe that this approach is conducive to learning both language and content (Lyster, 2007) as learners use language to make meaning (Halliday, 1993).

In 2001, the Chinese Ministry of Education responded to this call by issuing a historic policy that mandated teaching approximately 5 to $10 \%$ of the major university content courses (e.g., information technology, bio-technology, new material technology, finance, etc.) in English (Huang, 2011; Ministry of Education, 2001c). That policy and practice became known as "Chinese-English Bilingual Education," one of the major steps that the Chinese government has taken since the 1980s to enter the world arena, where English has become the lingua franca (Guo

Journal of Contemporary Issues in Education, 2012, 7 (1), Special Issue, pp.47-63

ISSN 1916-3460 () 2011 University of Alberta

http://ejournals.library.ualberta.ca/index.php/cpi/index 
$\&$ Beckett, 2007). The rationale for the policy is based on a belief that English is essential to the globalization process and that teaching content courses in English can help speed up Chinese people's mastery of English. The government mandated the policy on a trial basis but it is now "rattling across the country like a juggernaut" (Hu, 2008, p. 195) and at great speed (Feng, 2007, 2009; Wang, 2006). For example, the Chinese Ministry of Education revised the 2004 College English Curriculum Requirements, suggesting changes to EFL teaching, learning, and assessment approaches and requiring $10 \%$ of total undergraduate credits to be earned through the medium of English (Ministry of Education, 2007). In 2010, the Ministry of Education (2010) encouraged even more English medium university instruction to attract international students, and the number of English medium instruction courses during the 2009-2010 academic year at Fudan University, for example, reached 101 (Cai, 2010). Similar policies and practices extended to the K-12 system in various forms (see Feng, 2009; Knell, et al, 2007; Kong, 2009). This unprecedented push for large-scale Chinese-English bilingual education has been applauded by some, while it has also generated concerns among others.

In this article, we discuss justifications for and concerns about this policy and these practices, as well as the results of an empirical study conducted to address some of the concerns from university students' perspectives based on their lived experiences. This is one of the first empirical studies on content-based EFL in China and discusses some important issues from the perspectives of the students who are most impacted by it. Beckett $(2002,2005)$ suggest that students can have difficulty adjusting to new approaches to learning and that issues arising from such an adjustment need to be addressed. Findings of the study could extend our knowledge of content-based English education by providing perspectives from emerging contexts and by identifying important research and pedagogical questions for further study.

\section{Existing Work and Concerns}

As $\mathrm{Hu}$ (2005) suggests, the intensive and extensive push for English in China is justified by a widely-held belief that the country's position in the world and the pace of its modernization depend on national English proficiency. The Chinese government believed that English is of tremendous importance to nation's science, technology, economy, and reform as China enters the global era (see Gao, 2009; Huang, 2011) in increasing its international status (Lam, 2002). The market economy required English proficient workers (Gao, 2009; Lo Bianco, 2009). Such mentality pushed for a great leap forward in English education to produce what Vice Premier Li Liangqing referred to as Fuhexing Rencai (复合型人才, all rounded talents) (Gao, 2009). This means people who possess both strong competence in a foreign language, particularly in English and knowledge in specialized areas such as business, medicine, and information technology (Feng, 2007). Additionally, scholars and English teachers raised concerns about the efficiency and effectiveness of the traditional English education approach in China and argued for a better approach that enable English language learners to become more than good multiple choice test-takers and function communicatively (Lo Bianco, 2009). In responses, some universities started offering some of their disciplinary content courses in English. Some perceived English as a cultural capital for better life, path to civilization, and high self-esteem while others (see Hu, 2008; Gao, 2009), as a key to cross-cultural exchange, and technological progress (Lo Bianco, 2009). Others resisted 
expansion policy (Gil \& Adamson, 2011) claiming that it is expansion of western culture and waste of students' time because neither professors nor students have high enough English language proficiency to learn in it (see Lo Bianco, 2009). Some prominent English language specialists and scholars, particularly in Beijing, warned about potential negative consequences of the new policy and approach as they did not think universities were sufficiently resourced for it (see Gao, 2009) and other scholars stated that there is no correlation between the nation's progress and English proficiency (Hu, 2008).

Proponents of content-based EFL education in China often cite research findings on Canadian French Immersion (FI) to support their claims. However, FI is a complex phenomenon and numerous experimental studies have concluded that no clear evidence shows whether students make greater gains with French immersion instruction or without it (see Francis, Lesaux, \& August, 2006; Hu, 2008; Swain \& Lapkin, 1982). Lazaruk (2007), for example, concluded that FI students enjoyed significant linguistic, academic, and cognitive advantages with high levels of first and second language proficiency at no cost to their academic success, as well as "heightened mental flexibility and creative thinking skills, enhanced metalinguistic awareness, and greater communicative sensitivity (p. 605). However, Carey's (1991) within and between group comparison study showed that despite years of studying in French immersion, sixth and seventh graders did better in their first language (English) on reading tests. Clearly, French Immersion must be viewed critically, especially when they are "imported" to different contexts and used to support different purposes. French Immersion was designed to provide Anglophone students with French as a second language (Knell et al, 2007), and it was recently introduced to English as a Second Language (ESL) immigrant students in Canadian schools (Lazaruk, 2007). In both cases, its purpose is to provide students opportunities to learn French in much the same way as they learn their first language: "by being immersed in a language environment that promotes natural, meaningful communication" (Knell, et al., 2007, p. 396), a very different context from that commonly found in Chinese universities. French immersion students are instructed entirely or primarily in the students' second language by native or near native speakers of French, beginning at a young age and extending over a long period of time. This is very different from the "bilingual programs" at the university level in China, where students are being taught only a percentage of their courses in English, mostly by EFL speaking Chinese instructors, who are expected to improve their own English proficiency and their subject matter content knowledge in English.

Additionally, there is a severe shortage of qualified teachers to implement this approach and the effort to do so can result in a waste of resources (e.g., Hu, 2012). Janzen's (2008) review of research on content-based instruction in Australia, Canada, and the U.S. suggests there is general agreement that language plays a crucial role in comprehension and articulation of information that teachers must have a thorough understanding of their disciplinary language and substantial training in content-based instruction for this form of instruction to be successful. Such professional training is rare anywhere (see Fang \& Schleppegrell, 2008; Janzen, 2008), and it is almost non-existent in China. Furthermore, training teachers for content-based EFL can be a challenge (Cammarata, 2009), which is another reason to be realistic about the expectations for content-based EFL in China. 
Researchers also assert that the strong promotion of English could threaten Chinese language and culture and their roles in society (e.g., Feng, 2005, 2009; Guo \& Beckett, 2007; Hu, 2008), as well as minority and indigenous languages that are already in danger (Beckett \& MacPherson, 2005, 2009; Guo \& Beckett, 2007; Yang, 2005). These researchers argue that the global spread of English, of which the content-based English education policy in China is the most important recent development, is not only a product of colonialism but also a potent instrument of cultural control (Ashcroft, Griffiths, \& Tiffin, 1995; Pennycook, 1998). These theorists criticize the spread of English as "international linguistic hegemony," "linguicism," and "linguistic imperialism" (Phillipson, 1988), which may impoverish indigenous languages and cultures (Cooke, 1988; Phillipson, 1992) and privilege certain groups of people while harming others-namely, those who have less access to English language learning (Pennycook, 1995).

In sum, there have been unprecedented English language policy changes in China, particularly during the last decade, exemplified by the notable shift from form-focused language pedagogy to function focused content-based English education known as "bilingual education". Supporters of this approach hail it as the best approach for English language acquisition, something which they believe is the "golden key" to making the nation a powerful member of the global community, and often cite the "success" of Canadian French Immersion programs. Critics are concerned about the suitability of this approach to the Chinese context, citing inconclusive research findings and the lack of qualified teachers to implement the approach. They are also concerned about the potential threat of English to Chinese language and culture and to minority languages and cultures in China. However, due to the recent introduction of this approach and little empirical research on it, neither side has much research to support their claims and concerns (Lo Bianco, 2009). The current study was conducted to shed some light on these issues. Findings of the study help address the concerns discussed in the literature and contribute much needed empirical data to the mostly theoretical debate based on anecdotal evidence. They also lead to suggestions for further research as well as pedagogical recommendations for bilingual education and/or content-based second and foreign language education.

\section{Methodology}

\section{Research Site and Participants}

The present study was conducted to explore students' lived experiences and perceptions of the content-based EFL education at a Northwestern Chinese University. The University was established in the 1950s to offer foreign languages but has developed into an interdisciplinary institution with 25 schools and colleges that offer 34 specialties such as foreign languages, literature, economics, management, legal science, engineering, and pedagogy. At the time of data collection, it had an enrollment of 24,000 students, including master's, undergraduate, junior college, and short-term trainee students, and both local and international students. The university emphasized extensive international exchanges that included cooperative relations with 118 overseas universities and other educational institutions. The university participated in the Fulbright Program and had "two-campuses" programs with 77 universities in 21 countries, including Australia, Japan, France, Spain and 
Canada, for the training of undergraduate and graduate students. In the past six years alone, it sent 1,681 students to study or work abroad.

The School of Business where the participants were recruited was known for its excellent foreign language teaching environment. It offered a Master of Business Administration and a total of 8 undergraduate programs, including International Economy and Trade, Finance, Economics, Business Administration, Accounting, Marketing, Legal and Business English, with 2,670 students and 80 full-time faculty. The school had an "Innovation Teaching Team on International Business" and a "Bilingual Teaching Team," both of which had been nominated for the excellence-in-teaching awards at the provincial level. The Bilingual Teaching Team was described as English proficient experienced bilingual professionals with high academic attainment and considerable study abroad experience. The School aimed to teach an increasing number of courses in English, all of which would use original texts written in English.

The participants in this study were a class of 34 ( 32 female and 2 male) university juniors majoring in Finance. Their average age was 21, ranging from 20 to 23. 31 of the 34 students had taken an average of 1.58 (range from 1 to 3 ) content courses taught in English at the time of data collection. The other three students had taken such courses before, but were not taking them at the time of data collection. 25 of the participants took these courses because they were required, while six took them as electives. The participants' description of their learning contexts seemed to fall under what $\mathrm{Hu}$ (2008) labeled as Type D Bilingual Education context "characterized by an almost exclusive use of English as the language of instruction" (p. 200). Three of the students reported having passed TOEFL, 2 scoring 95 and 1 scoring 98, while six took IELTS with scores ranging from 5.5 to 7 (one 5.5, one 6, and four 7). 32 participants took the Band 6 Test with an average score of 552, the range being from 500 to 654 . The Band 6 Test uses a curved scale scoring system with the highest possible score being 720 and the lowest being 290. An average score of 552 indicates that the participants had high intermediate English language proficiency. A summary of information about the participants is presented in Table 1.

The participants for the study were recruited using a purposeful sampling method that allowed for recruiting a targeted group who could provide the information required for the study. The criteria for participant selection were student volunteers who had taken and/or were taking at least one content course in English at a Northwestern university that was implementing China's content-based English education policy.

\section{Data Collection and Analysis}

Data for this study were collected through a three-part open-ended questionnaire to 34 undergraduate students in finance major from April to September in 2009. Part I of the questionnaire solicited demographic information that included age, gender, English proficiency, number of years at university, and choice of courses. Part II of the questionnaire was open-ended and solicited students' thoughts on English medium content instruction focusing on their learning, expectations, and their perceptions of advantages and disadvantages of this approach. The questions in this part also solicited the participants' thoughts regarding their professors' 
Table 1: Participants' Background Information

\begin{tabular}{|c|c|c|c|c|c|c|c|c|c|c|c|}
\hline \multirow[b]{2}{*}{ Participant } & \multirow[b]{2}{*}{ Age } & \multirow[b]{2}{*}{ Gender } & \multirow[b]{2}{*}{ Grade } & \multirow[b]{2}{*}{ CET-6 } & \multicolumn{2}{|c|}{ Other Exam(s) } & \multirow[b]{2}{*}{ Current } & \multirow{2}{*}{\multicolumn{4}{|c|}{ Reason }} \\
\hline & & & & & TOEFL & IELST & & & & & \\
\hline 1 & 22 & $\mathrm{~F}$ & Junior & 580 & 95 & 7 & N/A & \multicolumn{4}{|c|}{ Required Course } \\
\hline 2 & 21 & $\mathrm{~F}$ & Junior & 517 & N/A & N/A & 1 & \multicolumn{4}{|c|}{ Required Course } \\
\hline 3 & 22 & $\mathrm{~F}$ & Junior & 586 & N/A & N/A & 1 & \multicolumn{4}{|c|}{ Required Course } \\
\hline 4 & 21 & $\mathrm{~F}$ & Junior & N/A & N/A & N/A & N/A & \multicolumn{4}{|c|}{ Required Course } \\
\hline 5 & 22 & $\mathrm{~F}$ & Junior & 563 & N/A & N/A & 1 & \multicolumn{4}{|c|}{ Required Course } \\
\hline 6 & 20 & $\mathrm{~F}$ & Junior & 538 & N/A & N/A & 1 & \multicolumn{4}{|c|}{ Required Course } \\
\hline 7 & 22 & $\mathrm{~F}$ & Junior & 534 & N/A & N/A & 1 & \multicolumn{4}{|c|}{ Required Course } \\
\hline 8 & 20 & $\mathrm{~F}$ & Junior & 598 & N/A & N/A & 1 & \multicolumn{4}{|c|}{ Required Course } \\
\hline 9 & 20 & $\mathrm{~F}$ & Junior & 500 & N/A & N/A & 2 & \multicolumn{4}{|c|}{ Required Course } \\
\hline 10 & 21 & $\mathrm{~F}$ & Junior & 447 & N/A & 5.5 & 1 & \multicolumn{4}{|c|}{ Elective } \\
\hline 11 & 21 & $\mathrm{~F}$ & Junior & 504 & N/A & N/A & 3 & \multicolumn{4}{|c|}{ Elective } \\
\hline 12 & 20 & $\mathrm{~F}$ & Junior & 550 & N/A & N/A & 1 & \multicolumn{4}{|c|}{ Required Course } \\
\hline 13 & 20 & $\mathrm{~F}$ & Junior & 604 & N/A & N/A & 2 & \multicolumn{4}{|c|}{ Required Course } \\
\hline 14 & 21 & $\mathrm{~F}$ & Junior & 560 & N/A & N/A & 1 & \multicolumn{4}{|c|}{ Required Course } \\
\hline 15 & 22 & $\mathrm{~F}$ & Junior & N/A & N/A & N/A & 2 & \multicolumn{4}{|c|}{ Required Course } \\
\hline 16 & 21 & $\mathrm{~F}$ & Junior & 510 & N/A & N/A & 2 & \multicolumn{4}{|c|}{ Required Course } \\
\hline 17 & 21 & $\mathrm{~F}$ & Junior & 604 & N/A & N/A & 2 & \multicolumn{4}{|c|}{ Elective } \\
\hline 18 & 22 & $\mathrm{~F}$ & Junior & 654 & N/A & 7 & 1 & & Requi & $\mathrm{d} \mathrm{Cou}$ & \\
\hline 19 & 20 & $\mathrm{~F}$ & Junior & 537 & N/A & 7 & 2 & & Requi & $\mathrm{d} \mathrm{Col}$ & \\
\hline 20 & 21 & $\mathrm{~F}$ & Junior & 612 & N/A & N/A & 2 & & Requi & $\mathrm{d} \mathrm{Col}$ & \\
\hline 21 & 21 & $\mathrm{M}$ & Junior & 534 & N/A & N/A & 3 & & Requi & $\mathrm{d} \mathrm{Cou}$ & \\
\hline 22 & 22 & $\mathrm{~F}$ & Junior & 518 & N/A & N/A & 1 & & Requi & $\mathrm{d} \mathrm{Cou}$ & \\
\hline 23 & 22 & $\mathrm{~F}$ & Junior & 580 & 95 & 7 & N/A & & Requi & $\mathrm{d} \mathrm{Cou}$ & \\
\hline 24 & 20 & $\mathrm{M}$ & Junior & 519 & N/A & N/A & 2 & & & ctive & \\
\hline 25 & 22 & $\mathrm{~F}$ & Junior & 581 & N/A & N/A & 2 & & Requi & $\mathrm{d} \mathrm{Col}$ & \\
\hline 26 & 22 & $\mathrm{~F}$ & Junior & 581 & N/A & N/A & 1 & & Requi & $\mathrm{d} \mathrm{Cou}$ & \\
\hline 27 & 20 & $\mathrm{~F}$ & Junior & 586 & N/A & N/A & 1 & & & ctive & \\
\hline 28 & 22 & $\mathrm{~F}$ & Junior & 584 & N/A & N/A & 1 & & Requi & $\mathrm{d} \mathrm{Cou}$ & \\
\hline 29 & 20 & $\mathrm{~F}$ & Junior & 515 & 98 & N/A & 1 & & Requi & $\mathrm{d} \mathrm{Cou}$ & \\
\hline 30 & 21 & $\mathrm{~F}$ & Junior & 438 & N/A & N/A & 2 & & & ctive & \\
\hline 31 & 22 & $\mathrm{~F}$ & Junior & 551 & N/A & 6 & 2 & & Requi & $\mathrm{d} \mathrm{Cou}$ & \\
\hline 32 & 21 & $\mathrm{~F}$ & Junior & 536 & N/A & N/A & 2 & & Requi & $\mathrm{d} \mathrm{Cou}$ & \\
\hline 33 & 22 & $\mathrm{~F}$ & Junior & 587 & N/A & N/A & 3 & & Requi & $\mathrm{d} \mathrm{Cou}$ & \\
\hline 34 & 23 & $\mathrm{~F}$ & Junior & 548 & N/A & N/A & 1 & & Requi & $\mathrm{d} \mathrm{Cou}$ & \\
\hline $\begin{array}{l}\text { Average } \\
\text { Age }\end{array}$ & 21 & $\begin{array}{l}\text { Average } \\
\text { Score }\end{array}$ & CET-6 & 552 & $\begin{array}{l}\text { Average } \\
\text { Course T }\end{array}$ & $\begin{array}{l}\text { Current } \\
\text { aken }\end{array}$ & 1.58 & $\begin{array}{l}\text { Ele } \\
\text { cti } \\
\text { ve }\end{array}$ & 6 & $\begin{array}{l}\text { Requ } \\
\text { ired }\end{array}$ & $\begin{array}{l}2 \\
5\end{array}$ \\
\hline
\end{tabular}

NCEEES = National College Entrance Exam, English Section

CET-6: College English Test, Band 6 Self: Self-improvement 
performance and roles, their mode of instruction, preference for instructors, texts and other learning resources, assignments, course formats, and their language of preference for learning subject matter content. Part III was also an open-ended questionnaire that solicited students' thoughts on English medium content learning, the advantages and disadvantages of English as a lingua franca, and possible perceptual changes after being in English medium content courses. The questionnaire was distributed bilingually (English and Chinese). Ten participants responded in English and the rest responded in Chinese.

\section{Data Collection and Analysis}

Data for this study were collected through a three-part open-ended questionnaire to 34 undergraduate students in finance major from April to September in 2009. Part I of the questionnaire solicited demographic information that included age, gender, English proficiency, number of years at university, and choice of courses. Part II of the questionnaire was open-ended and solicited students' thoughts on English medium content instruction focusing on their learning, expectations, and their perceptions of advantages and disadvantages of this approach. The questions in this part also solicited the participants' thoughts regarding their professors' performance and roles, their mode of instruction, preference for instructors, texts and other learning resources, assignments, course formats, and their language of preference for learning subject matter content. Part III was also an open-ended questionnaire that solicited students' thoughts on English medium content learning, the advantages and disadvantages of English as a lingua franca, and possible perceptual changes after being in English medium content courses. The questionnaire was distributed bilingually (English and Chinese). Ten participants responded in English and the rest responded in Chinese.

Responses in Chinese were translated into English by two graduate student research assistants and by the first author (all fluent in both languages) before coding, which was also carried out by three of us. In order to ensure inter-rater reliability, we translated and coded 40 percent of the data (15 participants' responses to parts II and III questions) individually and met to compare and contrast for similarities and differences of translations and coding, which turned out to be at the 96 percent level. The differences resulted from sentences and phrases dropped in translation and coding and slight discrepancies in translation. An example of a discrepancy is that the second author translated "zhangwo" as "master," while the other research assistant translated it as "learn," as did the first author. 100 percent agreement was reached through discussions among three of us. Responses to Part I of the questionnaire were translated by the second author, and revised and tabulated by both authors.

The data were analyzed quantitatively and qualitatively, but since the purpose of the study was to understand participants' views based on their lived experiences, rather than factors affecting their views, we did not compute inferential statistics. Following Beckett, Amaro-Jiménez, and Beckett (2010), we present descriptive statistics to help identify salient themes from the qualitative analysis (Spradley, 1980), using open coding, axial coding, and selective coding (Strauss \& Corbin, 1998). 


\section{Findings}

Data analysis revealed overwhelming support for content-based English education with a belief that this can be a good approach to learn English and content knowledge simultaneously and that English can impact China and its culture positively. The findings also indicate that some of the participants were critical of the approach, stating that it is "shallow content teaching" and suggesting that subject matter content be taught in Chinese. The participants praised their original English texts and expressed their preference for student centered learning.

\section{"Killing Two Birds with One Stone"}

Qualitative and quantitative analysis of the data revealed overwhelming support for content-based English education (or "bilingual education") in China. 73 percent of the students participated in the study (25 out of 34) were supportive, 38 percent (13) without reservation and 35 percent (12) with reservations. These students believed that teaching English and content simultaneously is like "killing two birds with one stone." 15 percent (3) were unsupportive of the approach and three percent (1) had no opinion. The remainder of the students were undecided. The students provided equally clear and firm justifications of their positions, regardless of whether they supported the approach or not, as illustrated in the excerpts below:

Very good. I can learn both content knowledge of my subject matter content and improve my English competence. (s. 5)

The combination of English and content knowledge is a way of "killing two birds with one stone." It's practical to learn both professional knowledge and English expression. (s. 8)

Courses taught in English may help to find a better job in the future since more and more multinationals register in China. I hope I can learn financial knowledge and what foreign students learn in universities. (s. 27)

The students (e.g., 5, 8, and 27 above) thought that content-based EFL instruction is a good approach because it is a way to learn English language, subject matter content, and learn in the way that foreign students learn, all of which are perceived to be helpful for securing better employment in foreign enterprises, joint ventures and cooperatively run enterprises in China.

\section{The Positive Impact of English as a Global Language on China and its Culture}

Eighty percent (28) of the students believed that English is a useful tool that must be learned, while 20 percent (6) thought there was no need for Chinese people to learn English.71 percent (24) of the students believed that English is a global language and learning it benefits China in general and enriches its culture in particular. The following 
excerpts illustrate these sentiments:

English is a global language, a useful tool. Using it in our daily lives should be helpful with joint venture businesses with foreigners. It's also beneficial for China to be connected to the world and help accelerate China's development by learning from foreign experiences. (s. 1)

English enriches Chinese culture. By engaging in English language learning, we would have a deeper understanding about the cultures in Western countries. I also found that there is a close connection between language and culture. Language is a reflection of cultural styles, ways of thinking, and attitudes of the people who speak that language. Thus, as it is the case with learning any language, we can experience different cultures by learning English. (s. 3)

I enjoy English as well as Chinese. I have to spread our Chinese culture. So, it's good for our country. But, as the globalization, I have to open my mind and broaden my heart to more cultures and things. So, I will insist on learning English to achieve my dream in English, spread Chinese culture. (s. 24)

The excerpt from student 1 suggests a belief that the promotion of English language through content teaching is beneficial because China needs to accelerate its development by establishing joint-ventures and learning from the experiences of foreigners. English, a global language, is the key if these goals are to be met. The excerpt from student 3 extends this sentiment by adding that learning English is enriching because in doing so Chinese people can learn about Western cultures, in particular, about the cultural styles, different ways of thinking, and attitudes of English speakers. The excerpt from student 24 takes this sentiment one step further with a specific note that learning English is beneficial because it can help the participant broaden her horizons in a global era and help her realize her dream of spreading Chinese culture. The remainder of the students, 29 percent (10 out of 30) were either unsure of or had mixed feeling about the spread of English on Chinese society and its language and culture.

\section{The Shallowness of Content Taught in English}

Ninety-nine percent (33) of the students thought that content taught in English by Chinese professors is shallow and does not meet their needs.

Teaching content knowledge in English is difficult for professors. It's also difficult for students to learn because their English is weak. The content knowledge presented in English is too shallow. It doesn't meet students' learning needs. (s. 11)

The content taught by Chinese professors in English is shallow and therefore not helpful for learning. Learning English is important, but it's just a tool. We can learn it as a language. We can translate subject knowledge into English. 
They should not teach us content knowledge in English and teach it shallowly. Professors' and students' English is not good. (s. 17)

There was no in-depth communication between professors and students. Their English is not good. It looked like we were having English reading class. If the combined English language content courses cannot be delivered well to provide more in-depth content knowledge. English should be taught separately. We can use it to understand our content knowledge later. English is just a tool anyway. (s. 5)

The students were clearly concerned about the depth of content knowledge delivered in English. The recurring sentiment was that they wanted more in-depth content knowledge, which they did not think was possible because of their own and their professors' English language proficiency. When asked to evaluate their own English language proficiency and that of their professors, 56 percent (19) of the students reported having average English language proficiency, while 35 percent (12) believed that their English was weak and resulted in their inability to understand some content taught in English and complete the required readings in English. 31 percent (10) of the students believed that their professors were English competent and good model for their learning in English, but 47 percent (16) thought their professors had limited English proficiency. 74 percent (25) of the students thought that subject content should be the priority in content courses and be taught in Chinese, leaving English to be taught in English language classes or as something to be learned as a basic tool.

Due to the inadequacy of the professors' and students' language proficiency, the content courses taught in English were somehow not at the deeper level. Content courses should prioritize the teaching of content knowledge and avoid becoming English reading class. (s. 10)

Due to their inadequate English proficiency, professors seemed to be always translating and repeating only what's in the textbooks rather being able to elaborate their points. Their pronunciation is poor. We don't often understand what they say (s.2)

... I think English should be taught as English and content should be taught as content in Chinese. This way, professors can go into the depth of knowledge. English is basic knowledge and tool that we should learn in this global village, anyway. (s.11)

The excerpts above indicate that some of the content courses taught in English may have become English language courses rather than courses in which they learned both business English and the finance content in English. It also suggests that at least some of the lectures were incomprehensible to students due to their professors' "poor" pronunciation.

On a similar note, 15 percent (5) of the participants preferred to be taught by native English speakers because their ways of thinking are different and possibly more reflective of 
the English language texts they are studying. Below are examples that represent their thoughts:

Because people using different language have quite a different way of thinking, a native speaker of English professor is more competitive to help us to understand the content written by English speaking professors more accurately. So, I think they should teach us. (s. 8)

Native English speakers are better for this kind of teaching because English is their language and so they can express themselves more freely and clearly, which should be helpful for our comprehension as well. (s. 32)

\section{Preference for Content Area Textbooks Written in English and a Student-Centered Approach}

82 percent (28) of the participants liked content area texts written in English by English speakers, saying that such textbooks were comprehensive and easy to understand. The rest of the participants did not have opinion on this.

The textbooks are good. They are comprehensive and easy to read. They are logically written, provided with many practical examples. It's like the authors want you to understand. The textbooks written by Chinese professors are not good. (s. 27)

English textbooks are good. They explain very well. They provide enough exercises and you can skip when you understand. Chinese texts are not good. These texts are very dense, too much information, and poorly written. I feel like they don't want you to understand it. Too many practice problems, too. (s. 32)

Participants in general made it clear, as did participants 27 and 32 above, that they prefer textbooks written in English by English speakers because they are easy to understand, logical, and include case scenarios that made sense to them.

Ninety-four percent (32) of the participants wrote that their content courses in English were teacher/lecture centered and expressed a preference for student- and seminar-centered approaches, as pointed out by students 1 and 9 in the following excerpts:

It's teacher centered. I think it would be more interesting and engaging if it's student centered. I'd like it to be student-centered because it will be more interesting and inspiring. (s. 1)

These courses are teacher-centered. It's not beneficial for the mastery of the knowledge, learning English and practicing English, or to express my opinion. It's good for resisting repressive teaching though because I don't have to say anything. (s. 9). 
It was clear that almost all participants disliked teacher/lecture-centered content teaching in English because it was boring, disengaging and repressive, and that they preferred student-centered and seminar style teaching and learning instead. They believed that the latter would be more interesting and inspiring and would be more conducive for learning content knowledge and practicing English, as indicated by participants 1 and 9 above.

\section{Conclusion and Discussion}

Several conclusions can be drawn from the findings of the present study. First, students who participated in the study supported the content-based EFL education advocated by some scholars or the English-Chinese bilingual education policy and practices promoted by the Chinese Ministry of Education. They believed that content-based EFL can foster simultaneous learning of English language and subject matter content (Lyster, 2007; Mohan \& Beckett, 2003) if it is implemented appropriately (e.g., both professors and students are equipped with adequate English language proficiency). An overwhelming majority of the students viewed learning English as beneficial for China's development in this global era and that it enriches Chinese culture by enabling students to learn from what they perceived as "more advanced Western cultures", thus confirming claims in the existing literature (e.g., Gao, 2009; Huang, 2011; Lo Bianco, 2009). Students also perceived English as an essential tool in preparing them for better employment opportunities in foreign business ventures, thus confirming the discussions in Gao (2009), Huang (2011), and Lo Bianco (2009). Such overwhelming support for content-based EFL from a utilitarian linguistic instrumentalist perspective, viewing English language as an essential tool for economic gains and social development (Kubota, 2011; Wee, 2008) with little criticism of its potentially negative impact on China, is somewhat surprising. It would be interesting to explore whether this is due to students' uncritical acceptance of their government's policies or to the fact that they genuinely believed that the policies are good for China in future studies.

Second, from their lived experiences in content-based EFL courses, students reported that content-based EFL can be problematic as these courses might turn into either English reading courses and/or "shallow" content courses when professors and students are not ready. As indicated clearly in the quoted responses, students did not feel the courses they took were successful in teaching adequate content knowledge in English language because of their own and their professors' limited English language proficiency. Lo Bianco (2009) raised a similar concern: neither professors nor students have sufficient English language proficiency to teach or learn the subject matter contents in the medium of English. The student participants in our study also reported that their understanding of professional knowledge in finance was often hampered by incorrect pronunciation of English of some professors. Similar findings have been reported by previous studies (Pan, 2007). Due to the shallowness of content taught in English, seventy-four percent of the students in our study requested that the content be taught in Chinese and that English be taught separately. Similarly, student participants in Beckett's (2005) study also thought that English should be taught separately from subject matter content. However, unlike the students in that study, who drew their conclusion as a result of educational, linguistic, and philosophical mismatches with their teachers, the students participated in the current study based 
their arguments on their perceived linguistic inadequacy of both professors and students.

The finding that ninety-nine percent (33) of the students reporting that content taught in English by Chinese professors is shallow and does not meet their needs is important. This challenges the core argument for content-based English to produce Fuhexing Rencai (复合型 人才) in order to help the nation achieve the global status (Lam, 2000) through science, technology, economic progress (see Gao, 2009; Huang, 2011), and quality education that enables students to develop intellectual and creative powers (see $\mathrm{Hu}, 2008$ ), and raise self-esteem (see Hu, 2008; Gao, 2009). Obviously, these goals are impossible to achieve if the teaching and learning are shallow as students pointed out because in order to make progress in any area and develop intellectual and creative powers require in-depth, not shallow, knowledge. As Feng (2007, p. 263) suggests, "Fuhexing Rencai are perceived as bilinguals who have the expertise in most forefront specialized fields and can, when need arises, use a foreign language to communicate with speakers of that language, especially native-speakers specialists and professionals in the fields." The student participants in our study reported that the shallow knowledge they learned in their Chinese-English bilingual programs may hinder the development of their specialized knowledge in finance or their competence in English. Feeling of shallow learning does not raise students' self-esteem either. In light of this finding, proponents of content-based English education in China need to rethink their arguments. This finding also suggests that it is important to use students' first language as the medium of instruction. This is consistent with the strong arguments for first language use in schools made by other scholars (Coelho, 2004; Cummins, 2009).

Third, based on their experience in content-based EFL courses, 82 percent of the students seem to have discovered a new textbook writing style and developed a strong preference for content area texts written in English by English speakers, saying that such textbooks are easier to understand. According to them, these texts, compared to texts written in Chinese by Chinese professors, are more logical, less abstract, and full of case scenarios that are helpful for comprehension. This has implications for text-book writing in China especially because there is little discussion about this aspect in the literature due to limited empirical research (see Tao, in press, for an exception).

A fourth conclusion we can draw seems to be that when new policies and approaches are introduced, students might expect new teaching practices as well. For example, participants in this study seemed to have expected a "corresponding" change in teaching practice from a teacher/lecture centered approach to a more student/seminar-centered approach, and they were disappointed when that expectation was not met.

This study suggests that contemporary Chinese university students are pragmatic and are willing to support new initiatives such as content-based EFL because they may well be beneficial for the country in general and for their own career prospects in particular. It could also mean that students are open to learning about and from other countries' best practices, such as textbooks that are more logically written and easier to understand; that they are active agents capable of evaluating policies and practices for themselves; and that they are capable of expressing their needs and preferences. What it certainly means is that, while the proponents of content-based 
EFL education may have students' support for the general direction the practice is taking and agreement that English is essential for China's further development, much more needs to be done before this approach can be successful.

Many issues need to be addressed in future studies. For example, researchers could conduct interviews and classroom observations for the purpose of triangulation (Spradley, 1980). If high intermediate English language proficiency, which the participants in the current study had, is insufficient, we need to explore the appropriate level of English proficiency necessary for better implementation of this form of English education. We need to further explore just how "shallow" the contents transmitted to students are and appropriate strategies to address this issue. If English proficient experienced bilingual professionals with high academic attainment and considerable study abroad experience teaching force cannot teach in-depth knowledge in English, we need investigate what level of professors' linguistics proficiency is needed for bilingual education. Finally, we should explore students' perspectives at different institutions and professors' lived experiences and perspectives on content-based EFL to further our understanding of the issues raised by the students in this study. Such investigations can help advance our understanding of bilingual education, content-based foreign language acquisition, and the impact of the spread of English globally and in Chinese contexts in particular, as well as help refine existing theories and generate new theories.

Meanwhile, professors who teach subject matter content in English can be made aware of students' perspectives and should be provided with inservice training to help address the issues raised by the participants in this study. Professors need more professional development focusing on improving their English proficiency in general and pronunciation in particular, as well as new teaching methods. More universities can send their subject content professors to English-speaking countries for training and those that have this practice already can expand it to more professors. Professors can also learn how to help their students improve their English and explore their content areas more independently, for example, through project-based approach (see Beckett \& Miller, 2006). Project-based teaching/learning is ideal because it is student-centered and involves articulating a plan and executing it, orally as well as in writing, which affords many opportunities for students to thoughtfully and critically learn both content knowledge and the language of content using the English language they want to improve. It also affords opportunities for other learning such as computer skills, as students can incorporate technology into their projects.

\section{Note:}

"S" refers to students (as in student participants). "S. 1" refers to student 1, "s. 2" refers to student 2, etc. Excerpts in plain font are translations from Chinese. Excerpts in italics are in the original language.

\section{References}

Ashcroft, B., Griffiths, G., \& Tiffin, H. (Eds.). (1995). The post-colonial studies reader. London: Routledge.

Beckett, G. H. (2002). Teacher and student evaluations of project-based instruction. TESL 
Canada Journal, 19(2), 52-66.

Beckett, G. H. (2005). Academic language and literacy socialization of secondary school Chinese immigrant students: Practices and perspectives. Journal of Asian Pacific Communication, 15(1), 191-206.

Beckett, G. H. \& MacPherson. S. (2005). Researching the impact of English on minority and indigenous languages in non-western contexts. TESOL Quarterly, 39(2), 299-307.

Beckett, G. H. \& Miller, P. (Eds.) (2006). Project-based second and foreign language education: Past, present, and future. Greenwich, CT: Information Age Publishing, Inc.

Beckett, G. \& Amaro-Jiménez, C., \& Beckett, K. (2010). Students' use of asynchronous discussions for academic discourse socialization. Distance Education, 31(3), 315-334.

Cai, J. G. (2010). Guanyu woguo daxue yingyu jiaoxue congxin dingwei de sikao [On repositioning college English]. Foreign Language Teaching and Research, 42(4), 306-308.

Cammarata, L. (2009). Negotiating curricular transitions: Foreign language teachers' learning experience with content-based instruction. The Canadian Modern Language Review, 65(4), 559-585.

Carey, S. T. (1991). The culture of literacy in majority and minority language schools. The Canadian Modern Language Review, 47, 950-976.

Coelho, E. (2004). Adding English: A guide to teaching in multilingual classrooms. Toronto, ON: Pippin.

Cooke, D. (1988). Ties that constrict: English as a Trojan horse. In A. Cumming, A. Gague, \& J. Dawson (Eds.), Awarenesses: Proceedings of the 1987 TESL Ontario Conference (pp. 56-62). Toronto: TESL Ontario.

Cummins, J. (2009). Multilingualism in the English-language classroom: Pedagogical considerations. TESOL Quarterly, 43(2), 317-321.

Fang, Z. H., \& Schleppegrell, M. (2008). Technicality and reasoning in science: Beyond vocabulary. In Z. H. Fang \& M. Schleppegrell (Eds.), Reading in secondary content areas: A language-based pedagogy (pp. 18-38). Ann Arbor: University of Michigan Press.

Feng, A. W. (2007). Introduction. In A. W. Feng (Ed.), Bilingual education in China: Practices, policies, and concepts (pp. 1-10). Clevedon, UK: Multilingual Matters.

Feng, A. W. (2007). Intercultural space for bilingual education. In A. W. Feng (Ed.), Bilingual education in China: Practices, policies, and concepts (pp. 259-286). Clevedon, UK: Multilingual Matters.

Feng, A. W. (2009). English in China: Convergence and divergence in policy and practice AILA Review, 22, 85-102.

Francis, D. J., Lesaux, N., \& August, D. (2006). Language of instruction. In D. August \& T. Shanahan (Eds.), Developing literacy in second language learners: Report of the national literacy panel on language-minority children and youth (pp. 365-413). Mahwah, NJ: Lawrence Erlbaum.

Gao, Y. H. (2009). Sociocultural contexts and English in China: Retaining and reforming the cultural habitus. In J. Lo Bianco, J. Orton, Y. H. Gao (Eds.), China and English: Globalization and dilemmas of identity (pp. 56-78). Bristol: Multilingual Matters.

Gil, J. \& Adamson, B. (2011). The English language in Mainland China: A sociolinguistic 
profile. In A. W. Feng (Eds.), English language education across greater China (pp. 23-45). Bristol: Multilingual Matters.

Guo, Y. \& Beckett, G. H. (2007). The hegemony of English as a global language: Reclaiming local knowledge and culture in China. Convergence: International Journal of Adult Education, 40(1-2), 117-132.

Halliday, M. A. K. (1993). Language in a changing world (Occasional Paper 13). Deakin, A.C.T.: Applied Linguistics Association of Australia.

Hu, G. W. (2005). English language education in China: Policies, progress, and problems. Language Policy, 4, 5-24.

$\mathrm{Hu}, \mathrm{G}$. W. (2008). The misleading academic discourse on Chinese-English bilingual education in China. Review of Educational Research, 78(2), 195-231.

Hu, G. W. (2012). Chinese-English bilingual education in PRC: Implications for language education for autochthonous ethnic minorities. In G. H. Beckett \& G. Postiglione (Eds.), China's integrationist language policy: Impact on the ethnic harmony (pp. 175-189). London: Routledge.

Huang, B. (2011). Economic development and the growing importance of the English language in Guangxi. In A. W. Feng (Eds.), English language education across greater China (pp. 212-227). Bristol: Multilingual Matters.

Janzen, J. (2008). Teaching English language learners in content areas. Review of Educational Research, 78, 1010-1038.

Knell, E., Qiang, H., Pei, M., Chi, Y., Siegel, L.S., Zhao, L., \& Zhao, W. (2007). Early English immersion and literacy in Xi'an, China. Modern Language Journal, 91(3), 395-417.

Kong, S. (2009). Early English immersion and literacy in Xi'an, China. The Canadian Modern Language Review, 66(2), 233-267.

Kubota, R. (2011). Questioning linguistic instrumentalism: English, neoliberalism, and language tests in Japan. Linguistics and Education, 22, 248-260.

Lam, A. (2002). English in education in China: Policy changes and learner experiences. World Englishes, 21(2), 245-256.

Lazaruk, W. (2007). Linguistic, academic, and cognitive benefits of French immersion. The Canadian Modern Language Review, 63(5), 605-628.

Lo Bianco, J. (2009). English at home in China: How far does the bond extend. In J. Lo Bianco, J. Orton, Y. H. Gao (Eds.), China and English: Globalization and dilemmas of identity (pp. 192-210). Bristol: Multilingual Matters.

Lyster, R. (2007). Learning and teaching languages through content: A counterbalanced approach. Philadelphia: John Benjamins.

Ministry of Education of the People's Republic of China. (2001). Daxue jiaoyu zhiliang gaijing guize [Guidelines for improving the quality of undergraduate teaching]. Beijing: Ministry of Education.

Ministry of Education the People's Republic of China. (2007). Daxue yingyu kecheng yaoqiu [College English curriculum requirements (Document No. 3)]. Beijing: Department of Higher Education, Ministry of Education.

Ministry of Education the People's Republic of China. (2010). Plan for international students' study in China. Retrieved from http://202.205.177.9/edoas/website18/52/info1285655371911352.htm 
Mohan, A., \& Beckett, G. H. (2003). A functional approach to content-based language learning: Recasts in causal explanations. The Modern Language Journal, 87, 421-432.

Pan, J.Z. (2007). Facts and considerations about bilingual education in Chinese universities. In A. W. Feng (Ed.), Bilingual education in China: Practices, policies, and concepts (pp. 200-215). Clevedon, UK: Multilingual Matters.

Pennycook, A. (1995). English in the world/The world in English. In J. W. Tollefson (Ed.), Power and inequality in language education (pp. 34-58). Cambridge, UK: Cambridge University Press.

Pennycook, A. (1998). English and the discourses of colonialism. London: Routledge.

Phillipson, R. (1988). Linguicism: Structures and ideologies in linguistic imperialism. In J. Cummins \& T. Skuttnab-Kangas (Eds.), Minority education: From shame to struggle (pp. 339-358). Avon, UK: Multilingual Matters.

Phillipson, R. (1992). Linguistic imperialism. Oxford: Oxford University Press.

Spradley, J. P. (1980). Participant observation. Fort Worth, TX: Harcourt.

Strauss, A., \& Corbin, J. (1998). Basics of qualitative research: Techniques and procedures for developing grounded theory (2nd ed.). Thousand Oaks, CA: Sage.

Swain, M. (1995). Three functions of output in second language learning. In G. Cook \& B. Seidlhofer (Eds.), Principle and practice in applied linguistics: Studies in honour of H.G. Widdowson (pp. 125-144). Oxford: Oxford University Press.

Swain, M. \& Lapkin, S. (1982). Evaluating bilingual education: A Canadian case study. Clevedon: Multilingual Matters.

Tao, X. (in press). Essence or practice? Conflicting cultural values in Chinese EFL textbooks: A discourse analysis. Discourses: Studies in the Cultural Politics of Education.

Wang, L. F. (2006). Shuangyu jiaoxue yu shuangyu jiaoyu [Bilingual instruction and bilingual education]. Jingjishi, 1, 113-114.

Wee, L. (2008). Linguistic instrumentalism in Singapore. In P.K.W. Tan, \& R. Rubdy (Eds.), Language as commodity: Global structures, local market places (pp. 31-43). London: Continuum.

Yang, J. (2005). English as a third language among China's ethnic minorities. International Journal of Bilingual Education and Bilingualism, 8(6), 552-567.

Zhang, W. Y. (2001). Riben yingyu jiaoyude gaige dungxiang [The Japanese English education reform movement]. Waiyu Jie, 5, 33-36.

Zhang, Z. B. (2003). Yetan woguo waiyu jiaoxue de wenti [Discussions of our country's foreign language education reform also]. Foreign Language, 4, 1-6. 